\title{
INTERNATIONAL CONFERENCE BALKAN AND BALTIC STATES IN UNITED EUROPE: HISTORY, RELIGION, AND CULTURE III
}

\section{9-11 OCTOBER 2017, VILNIUS, LITHUANIA}

The $3^{\text {rd }}$ international conference Balkan and Baltic States in United Europe: History, Religion, and Culture was held in the Lithuanian Institute of History (Vilnius) on 9-11 October 2017. This conference was one of the events to take place in preparation for the centenary of the independence of the Republic of Lithuania. On 16 February 1918, Lithuania became an independent state, and one of the main actors in this event was Patriarch of the Lithuanian national rebirth, Jonas Basanavičius (1851-1927). He was a historian, folklorist, ethnologist, medical doctor, and politician, who worked in Bulgaria for almost a quarter of a century. So, he is a historical and cultural symbol of the unity of the Baltic and Balkan states. This was one of the reasons for holding this conference in Lithuania.

Ethnologists, folklorists, historians and anthropologists from Austria, Bulgaria, Estonia, Finland, Latvia, Lithuania, Romania, Russia, Turkey, and the United Kingdom gathered for three exciting days of panels, sessions, keynotes, discussions, and a tour. The conference was organised by three institutions: the Department of Ethnology and Anthropology, Lithuanian Institute of History; the Balkan Ethnology Department, Institute of Ethnology and Folklore Studies of the Bulgarian Academy of Sciences; and the International Society for Balkan and Baltic Studies (organising committee: Ekaterina Anastasova and Žilvytis Šaknys (heads), Svetoslava Toncheva and Audrone Daraškevičienè (secretaries), Marianka Borisova, Mila Maeva, Rasa Paukštytė-Šaknienė, Rasa RačiūnaitèPaužuolienė, Irma Šidiškienè).

The conference continued the discussions which had begun at the Institute of Ethnology and Folklore Studies of the Bulgarian Academy of Sciences in Sofia, dedicated to processes of the EU integration in the regions of the Balkans and the Baltics, discussed at the conference Balkan and Baltic States in United 


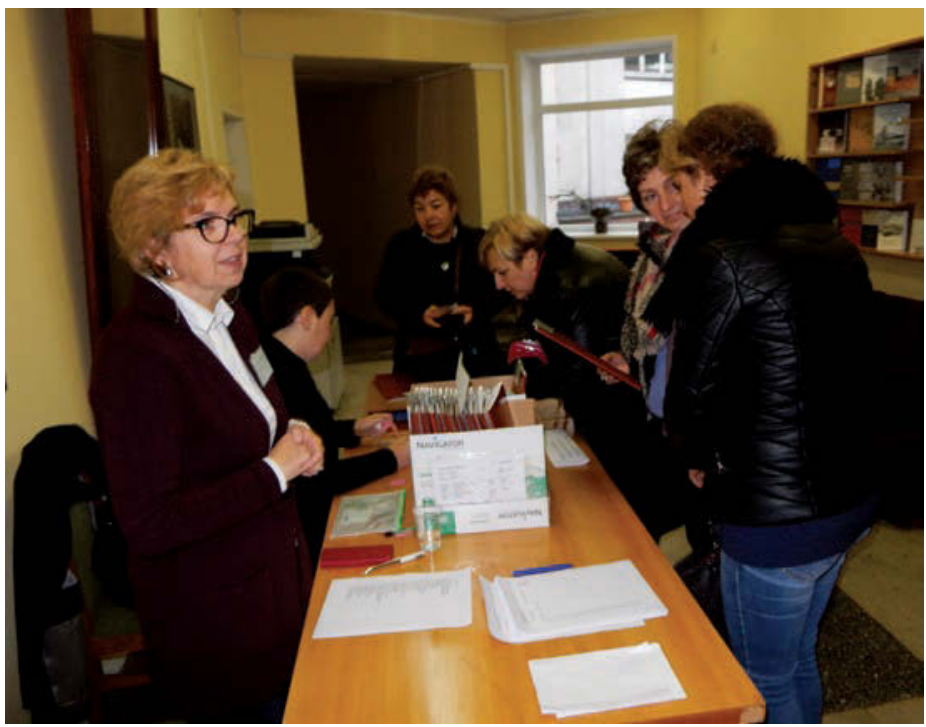

Figure 1. Registration. Irma Šidiškienè and Rasa Paukštyte Šaknienè meet the first participants of the conference. Photo by Žilvytis Šaknys, Vilnius, 2017.

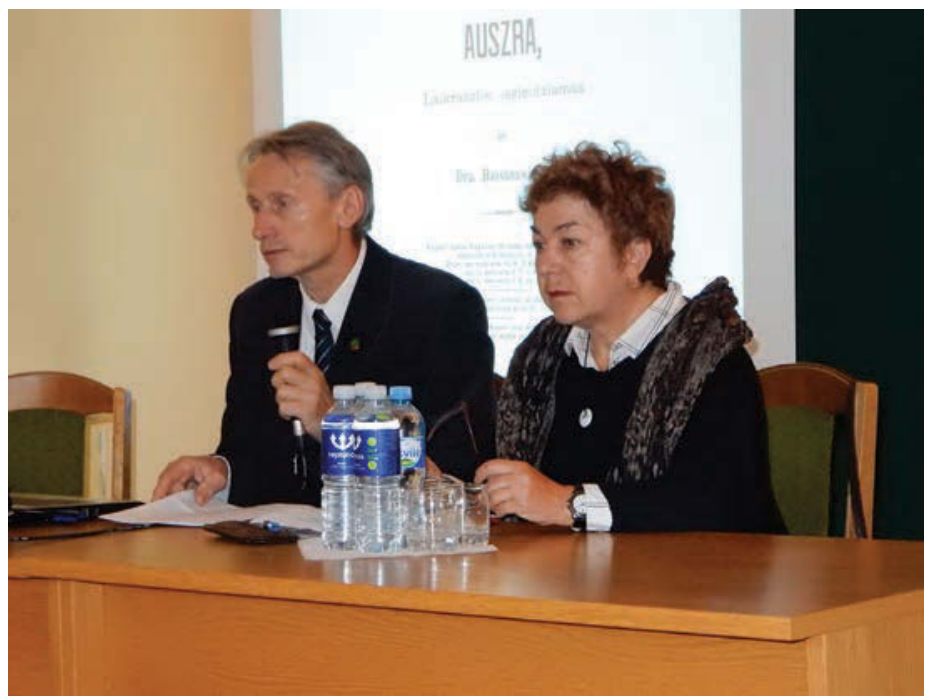

Figure 2. First report. Rimantas Miknys and Veneta Yankova. Photo by Žilvytis Šaknys, Vilnius, 2017. 
Europe: History, Religion, and Culture (October 2008) and Balkan and Baltic States in United Europe: History, Religion, and Culture II (October 2014).

The first conference panel under the heading History, Memory, Identity was opened by the director of the Lithuanian Institute of History, Rimantas Miknys (Vilnius, Lithuania). In his presentation "Hermeneutics of Jonas Basanavičius", he reached the conclusion that life in Bulgaria had a decisive influence on the Lithuanian State Patriarch Jonas Basanavičius. Arūnas Vaicekauskas (Kaunas, Lithuania) made a presentation titled "Hittites, Bulgarian Folklore and J. Basanavičius' Theory on Origins of Lithuanians", in which he presented a hypothesis of the origin of Lithuanians created by J. Basanavičius. According to this hypothesis, Lithuanians' ancestors came to their current homeland from the southern Balkans. Veneta Jankova (Shumen, Bulgaria) analysed the historical memory of the Lithuanian and Bulgarian Tatars in her presentation. She presented contemporary manifestations of historical memory: images of the past, the reinterpretation of history, the construction of one's own historical story and its relation to the national narrative. Skaidrè Urbonienè (Vilnius, Lithuania) in her presentation "Monuments to Commemorate Lithuanian Independence: Why Crosses?" discussed the campaign to build monuments to commemorate the 10th anniversary of Lithuanian state independence in 1928. She concluded that this campaign was a successful attempt to revive traditional cross-crafting, and to embed wooden memorial monuments as signs of Lithuanian national identity. Vildane Dinç and Artum Dinç (Bursa and Ankara, Turkey) analysed the imagery of Bulgarian socialism in the memory of the Turkish national minority. They explored imagery patterns in the memories, art, and albums created by the Turkish national minority, focusing on the period from the inauguration of the socialist regime until 1989. They revealed how the Turkish national minority perceived and reacted to the regime and developed strategies to survive in socialist Bulgaria. Ana Pascu (Bucharest, Romania) read a paper titled "The Narrative Constitution of Identity: The Case of the Pastoral and Mine Worker's Communities from Valea Jiului's Region (Romania)". She discussed the ways in which communities in the Valea Jiului region construct their social identity in the period when the coal mines are closing one by one, leading to increased poverty and depopulation, turning an area rich in natural and cultural resources into a marginal zone.

The second panel, Religion and Sacral Places, was opened by Robert Parkin's (Oxford, UK) presentation "How Świebodzin Got Its Statue of Jesus: Reflections 
on Sacred Spaces and Religious Tourism". Parkin described the history of the statue of Jesus Christ in Świebodzin (Poland) as not being associated with any miracle. Comparisons were made with the Lithuanian religious site of Šiluva, which is associated with a miracle (a vision of the Virgin). The questions were raised about just what we mean by such concepts as sacred space and pilgrimage. Solveiga Krumina-Konkova (Riga, Latvia) in her presentation "Religion in the Post-liberal time" declared that the case of the post-Soviet countries is interesting in that here the post-liberal spiritual tendencies exist alongside expressly liberal and also excessively totalitarian streams of thought. Rasa RačiūnaitèPaužuolienè (Kaunas, Lithuania) made a presentation titled "Religious Identity of Bulgarian Catholics' Communities", in which she revealed that there are some different characteristics and peculiarities within the local and regional religious identities of Bulgarian Catholic confessional communities. Inese Runce (Riga, Latvia) read a paper titled "The Spiritual Practice of Latvian Roman Catholic Families under the Soviet Regime and Its Influence Today”. She announced that the community of the Roman Catholic Church in Latvia has been less affected by processes of secularisation in comparison with other religious communities in Latvia. Jolanta Kuznecoviene (Kaunas, Lithuania) in her presentation "Liberal Democracy and the Voice of the Roman Catholic Church in Public Life of Lithuania" analysed the activity of Lithuanian Catholic Church in the public life of Lithuania in the period 1990-2015. She concluded that even though the state was (and still is) formally separated from church, in practice the state regards the Lithuanian Catholic Church as an influential actor in the political arena, whose voice often determines the final outcome of political decisions and legislation. Maria Mateoniu (Bucharest, Romania) in her presentation "The Tension between Communism and Orthodoxy in the Memory of Saint Nicholas' Monastery" tried to reveal how the nuns of the Saint Nicolae Monastery (Romania) relate to the ecclesiastical authority, the state, and society. Her purpose was to investigate some reflections on Eastern Christianity. Mare Kõiva’s (Tartu, Estonia) presentation titled “Inventing Sacred Places" was mostly based on Estonian and Bulgarian material and concentrated mainly on a) energy pillars, and b) so-called grassroots memorials or cultural memory fields created for a certain place. She characterised the creation of memorial sites initiated by Roman Espenberg-Haavamäe in the 1930s, which has now grown into a multi-faceted movement. Kõiva concluded that all these places share a common pattern - new objects make new identities, forms of 
sacrality and belonging. Mila Maeva (Sofia, Bulgaria) described the Seventhday Adventist churches in Bulgaria and the Baltic States. Her paper focused on the historical development of this church and its cultural influence on the local population. The main aim was to describe and analyse the multi- and transnational religious and cultural ties between them as well as their specifics in each country. Svetoslava Toncheva (Sofia, Bulgaria) in her paper "Buddhism in Bulgaria - Dimensions, Specifics and Distribution" declared that in the last decades the never-before-seen Eastern spiritual ideas and practices have spread into the Western world. The presentation's focus was on the specifics and forms of the spread of Buddhism in Bulgaria, with an attempt to show a better understanding of its functionality and place within Bulgarian culture. Monika Balikienè (Vilnius, Lithuania) in her presentation "An Enterprising and Subtle World of Magic Where Nothing Comes for Free" announced that the glorious rise of magic in contemporary Lithuania was obvious. Her paper was based on personal experience gained over the past 17 years, interviewing more than 300 males and females of different ages and educational backgrounds about their life experience concerning evil-eye diseases, energy vampirism, magic healing, and bewitchment of males using menstrual blood in different parts of Lithuania.

The second day of the conference and the third panel, Ethnicity and Ethnic Cuisine, was opened by Sergej Rychkov (Kazan, Russia). He presented a paper titled "The Religious Factor of the Gastronomic Behaviour of Urban Muslims in the Context of the Market Behaviour of the Subjects of Public Catering", in which he analysed culinary problems of Muslim ethnic groups (Tatar, Bashkir, Azerbaijani, Uzbek, Tajik, and others) in Russia. Galina Miškinienè (Vilnius, Lithuania) gave a presentation titled "Culinary Heritage of the Lithuanian Tatars". The Tatars, who came from the Kipchak steppes and the Crimea, brought with them a specific culture. Under the influence of Western European civilization, the culture of the Lithuanian Tatars changed and acquired new features. This process was analysed by the speaker through Tatar culinary art. Nadezhda Rychkova (Kazan, Russia) showed in her presentation "Everyday Meal Etiquette in the Food Culture of Urban Tatars - Muslims" that in the food culture and etiquette Muslim Tatars perceive themselves as a part of the Islamic world. The last presentation of the panel - "Factors of Identification and Consolidation of Ethno-territorial Groups of Tatars (on the example of the Volga and Lithuanian Tatars)" by Rozalinda Musina (Kazan, Russia) tried to compare ethnic and cultural identity of the Tatars living in Lithuania and the Volga region. 


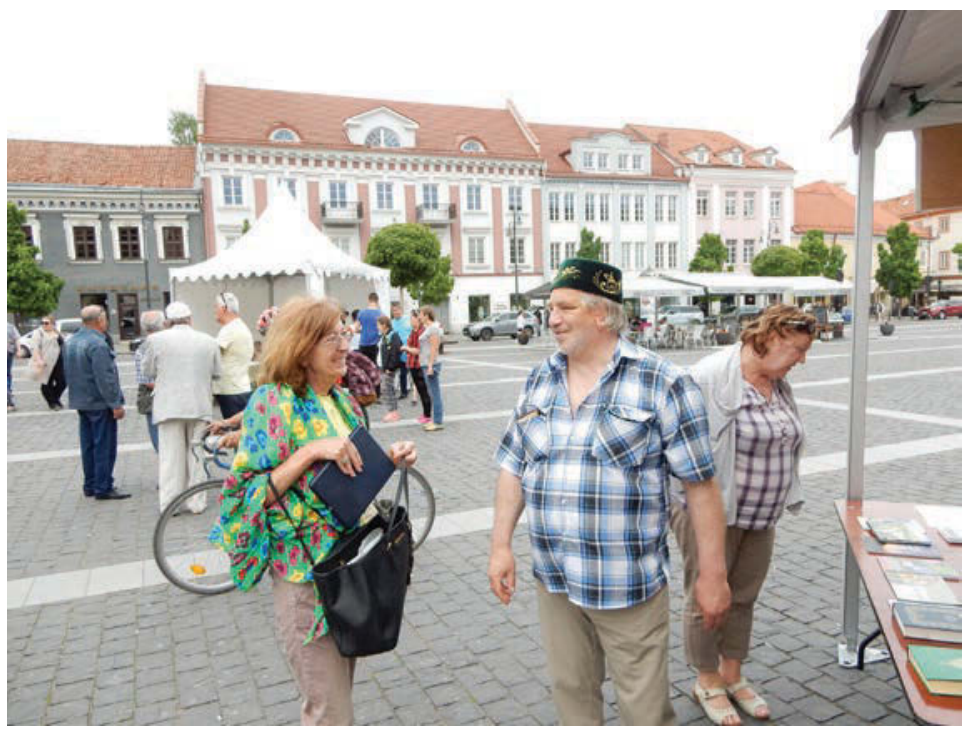

Figure 3. Ekaterina Anastasova's discussions about the conference with council of Tatars Community of Neméžis - Tairas Kuznecovas. Photo by Žilvytis Šaknys, Vilnius, 2017.

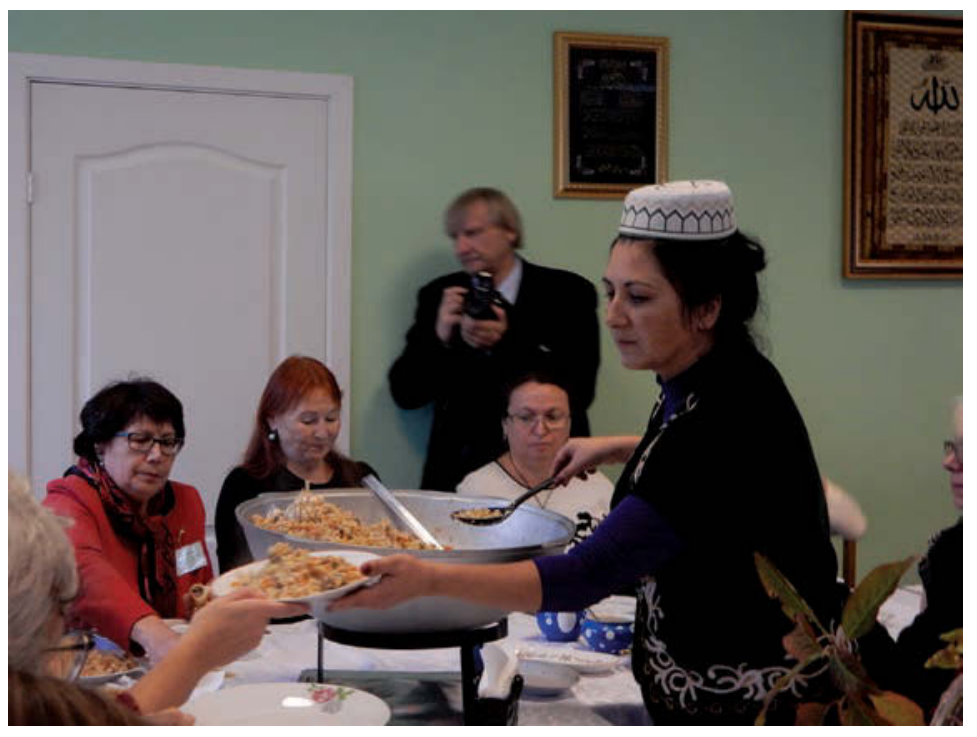

Figure 4. Traditional Tatar dishes in Nemèžis. Photo by Žilvytis Šaknys, Nemėžis, 2017. 
Meeting with the Nemèžis Tatar community finished the programme of the second day of the conference. Participants became acquainted with the history, culinary heritage, and traditions of this community. The organisers and participants of the conference are thankful to Tairas Kuznecovas, chairman of the Neméžis Community of Tatars.

The third day of the conference and the fourth panel, Ritual, Fasts, and Leisure Time, was opened by Rasa Paukštytė-Šaknienès (Vilnius, Lithuania) presentation "Lithuania and Bulgaria: Family Festivals in Contemporary City". Paukštyté-Šaknienė presented a comparative research of family rituals in Vilnius and Sofia, arguing that the comparison reveals many common features in both countries: "double ritual year" in the era of socialism and the disappearance of the contrast between family and public holidays at the end of the $20^{\text {th }}$ and the beginning of the $21^{\text {st }}$ centuries. Irma Šidiškienè (Vilnius, Lithuania) made a presentation titled "Cultural Aspects of the Co-workers' Community in Lithuanian and Bulgarian Cities". She drew attention to the fact that the dates and the rituals of the same festival do differ in both countries. Another difference lies in the fact whether people choose to celebrate or commemorate feasts with their colleagues or not. Žilvytis Šaknys (Vilnius, Lithuania) read a paper "Leisure and Friends' Festivities in Vilnius and Sofia". He aimed to answer the question how friendship is perceived and in what ways it is supported in two different $\mathrm{EU}$ countries, paying particular attention to how friendship functions in the perspective of the ritual year.

Figure 5. Žilvytis Šaknys. Photo by Andres Kuperjanov, 2017.

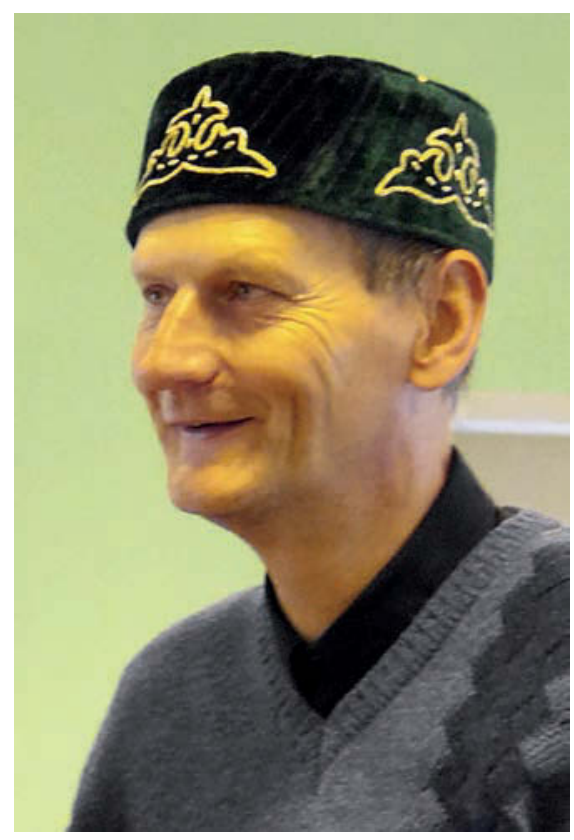


News and Reviews

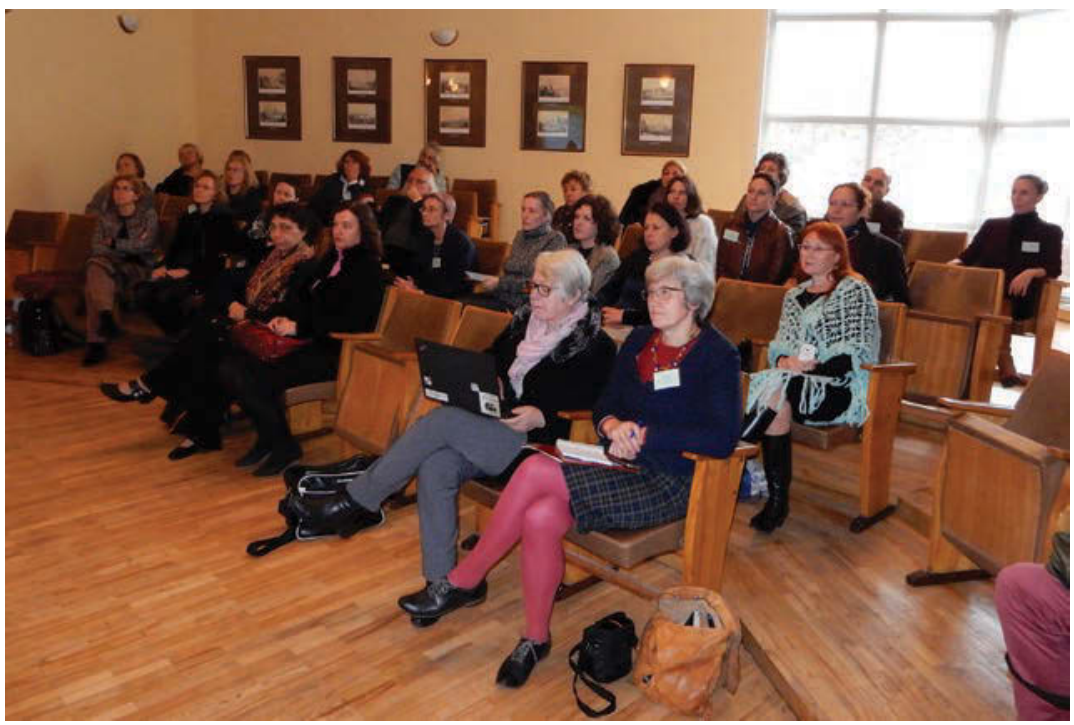

Figure 6. Third day of conference. Photo by Žilvytis Šaknys, Vilnius, 2017.

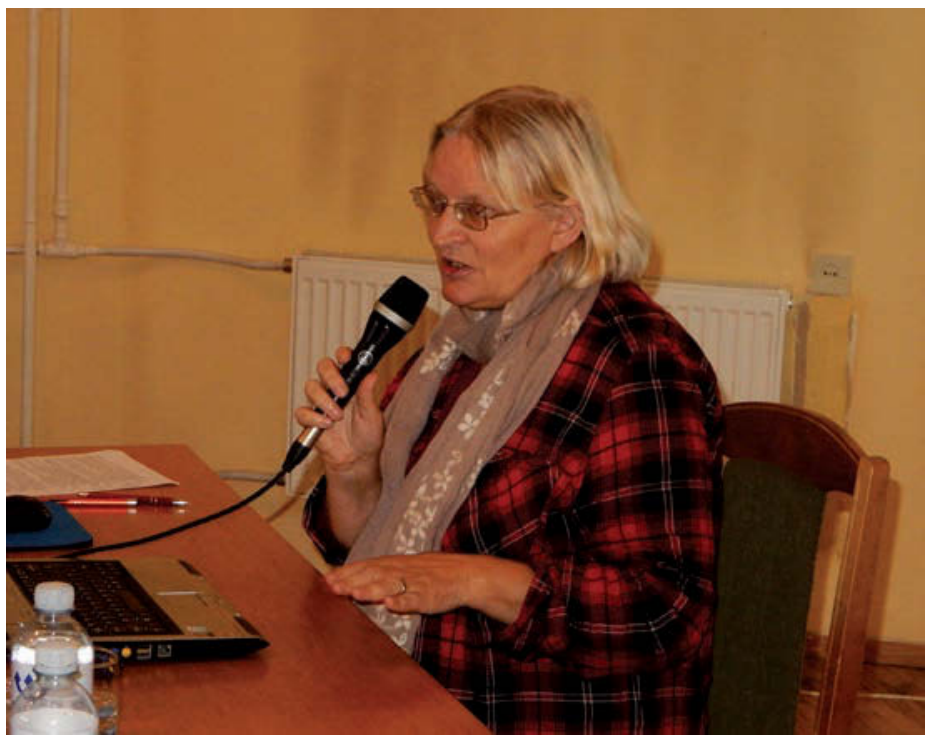

Figure 7. Closing of conference, Mare Kõiva. Photo by Žilvytis Šaknys, Vilnius, 2017. 
Lina Petrošienè (Klaipeda, Lithuania) in her presentation "Reflections of the Celebration of Shrovetide in Different Countries of the World in the Lithuanian Periodicals of the Early Twentieth Century" reviewed the publications about Shrovetide festival in the Lithuanian press at the beginning of the $20^{\text {th }}$ century. The author pointed out that these publications reflect the aspirations of the society of that period to integrate into the Western European and global cultural context as soon as possible. Svetlana Ryzhakova (Moscow, Russia) in her presentation "India in the Baltic Countries: Hindu Rites and Practices in Latvia and Lithuania Today" argued that the heritage of India is a very important source of inspiration for alternative religions in the Baltic States, especially for Latvians and Lithuanians.

In the $5^{\text {th }}$ panel, Migrants and Migration, Akvilè Motuzaite (Turku, Finland) read a presentation "Calendar Festivals as a Form of Transnationalism and Cultural Strategy in the Mixed Finnish-Lithuanian and Greek-Lithuanian Families". The author revealed that the calendar festivals celebrated in a particular context of emigration - within mixed families - acquire specific meanings from the individual and communal point of view. Mariyanka Borisova Zhekova (Sofia, Bulgaria) read a paper titled "Cultural Heritage Abroad: School Feasts Celebrated in the Educational Institutions of Bulgarian Immigrant Communities". She argued that the Bulgarian school festivals that are celebrated in schools of the Bulgarian community abroad hold a special place in the calendar of festive events, often turning into a festival for the entire community, and forge the cultural identity of adolescents in the context of immigration, giving them new perspectives and popularising Bulgarian culture abroad.

The $6^{\text {th }}$ panel was dedicated to the topic of tradition and innovation. Tatiana Minniyakhmetova (Innsbruck, Austria) in her presentation "Slavic-Baltic Space through the Prism of Magic Books" reviewed the history of some magic books that reached the Russians through the Southern Slavs and the Baltic regions. Irina Stahl (Bucharest, Romania) made a presentation titled "Sudden Death Memorials: A Study in an Urban Context". She noted that since 1990, Bucharest has been subject to a significant increase in the number of memorials erected in places where people unexpectedly lost their lives. Stahl discussed a particular set of circumstances related to the fall of communism and the regained freedom of religious expression that has led to the proliferation of such memorials. Andres Kuperjanov (Tartu, Estonia) in his paper "Sacral, Cultural and Memorial Places Related with Water" analysed the role of water in Bulgarian and Estonian 
culture and society. Milena Lyubenova's (Sofia, Bulgaria) presentation “Traditional Practices and Contemporary Expression of the Feast of St. Haralambos the Wonderworker in Bulgaria" focused on traditional practices related to the patron saint of beekeepers and the contemporary expression of the feast in the local community. Jonas Mardosa (Vilnius, Lithuania) in his paper "The Feast of the Pentecost in the Vilnius Calvary: Historical Perspective and the Present" noted that the celebration of the Feast of the Pentecost was renewed in the Vilnius Calvary after the collapse of the Soviet regime. He argued, however, that the modernisation of society and the strengthening of its secular layer has ensured a much more purified religious form for the revived tradition. Marju Kõivupuu (Tallinn, Estonia) presented empirical examples from Estonia that focused on particular heritage practices and communities in their specific sociocultural contexts in her paper titled "Inventory of Intangible Cultural Heritage: Estonia’s Example”. Gaila Kirdienè (Vilnius, Lithuania) in her paper "Ancient Links between the Baltic and Balkan Fiddling and Their Contemporary Interpretations" highlighted some links between fiddle playing customs in the Baltic and Balkan countries. Anete Karlsone's (Riga, Latvia) presentation "Actuality of Traditional Skills in Contemporary Cultural Environment" asserted that traditional skills and knowledge continue to maintain their place in society even today, when various information streams are becoming more and more active. Audronė Daraškevičienè (Vilnius, Lithuania) examined the problem of the moral education of children in the everyday lives of families in contemporary Lithuania. She argued that the principle of adult and child egalitarianism starts to predominate in child education. Nijolè Pliuraitė-Andrejevienè (Rumšiškès, Lithuania) in her presentation "Toys and Expression of Ethnic Identity in Soviet Lithuania: Ethnographic Dolls and Sculpturettes" noted that during the Soviet period some artists continued searching for Lithuanian identity through the creation of dolls. She examined this process and showed how it was possible, by using the "language of toys", to transfer the values of ethnic identity to the younger generation in the most unfavourable conditions.

The conference was concluded with discussions about the future perspectives. 